\title{
THE EFFECT OF BACITRACIN ON RENAL FUNCTION
}

\author{
By JOHN H. MILLER, ROGER K. McDONALD, AND NATHAN W. SHOCK \\ (From the Section on Cardiovascular Diseases and Gerontology, National Institutes of Health, \\ Bethesda, Maryland, and the Baltimore City Hospitals, Baltimore)
}

(Submitted for publication August 24, 1949; accepted, December 5, 1949)

Following the discovery by Johnson, Anker, and Meleney of the polypeptide antibiotic substance, bacitracin, in culture filtrates of a strain of $B$. subtilis (1), this drug has been administered to a large number of patients with a variety of bacterial infections (2-5).

In early clinical studies, recognition of the toxic manifestations of bacitracin lagged behind observations on the therapeutic efficacy of this antibiotic. Recent reports, however, have indicated an increasing awareness of the nephrotoxic properties of commercial preparations of bacitracin administered parenterally to the human $(2,5)$.

Animal studies have demonstrated that bacitracin is nephrotoxic for the mouse, rat, and monkey. Following parenteral administration of bacitracin in the mouse, tubular degeneration and necrosis occurred. Although the glomerular tuft appeared normal, Bowman's space was distended with coagulum (6). Similar findings of tubular injury have been reported in the rat ( 7$)$. Following the administration of bacitracin in the monkey, proteinuria and glycosuria occurred. Again the histologic findings were those of tubular degeneration and necrosis (8).

During the course of a clinical study evaluating the therapeutic efficacy of bacitracin in human syphilis, 148 patients with early syphilis received the drug parenterally in dosages ranging from 200 units per kilogram body weight every 12 hours for four days up to 400 units per kilogram body weight every six hours for seven days. All of the 148 patients developed proteinuria during the course of therapy (9). Characteristically, proteinuria was absent at 36 hours after the institution of parenteral bacitracin therapy and present at 60 hours. Urinary protein was at a maximum during the first 24 or 48 hours after its appearance and then decreased rapidly in spite of continuation of bacitracin therapy. The range of maximal proteinuria in individuals was from 0.1 gram to 19.6 grams in 24 hours, with a mean of 5.6 grams.
Microscopic examination of the urine revealed numerous epithelial cells and casts during the period of proteinuria. Red blood cells were present only rarely.

There was no relationship in this group of patients between the degree of proteinuria and either the daily dosage of the drug, the total amount of drug administered, or the duration of the therapeutic course. Furthermore, no difference in nephrotoxicity was discernible between various lots of bacitracin in spite of the fact that later preparations were considerably improved with regard to purity and potency. ${ }^{1}$ There was, however, great individual variation in nephrotoxicity as measured by quantitative determination of urinary protein in patients receiving the same lot in the same dosage schedule.

In Figure 1 are shown the mean daily values for proteinuria in a group of 29 patients with early syphilis who received 400 units of bacitracin per kilogram body weight at six hour intervals over a period of seven days. Figure 2 shows, in similar fashion, proteinuria in a group of $15 \mathrm{pa}-$ tients with early syphilis who received only two injections of bacitracin of 1,500 units per kilogram body weight 24 hours apart. The curves are essentially the same. Similar curves of proteinuria were obtained in individuals receiving but a single injection of bacitracin and in individuals receiving the drug in dosages of 200 to 400 units per kilogram body weight at six to 12 hour intervals over a period of four to seven days. It is of interest that proteinuria appeared at the same time in all groups. Also of interest is the rapid decline in the magnitude of proteinuria (Figure 1) even though administration of the drug was continued in the same dosage.

1 The following lots of bacitracin were used in the treatment of human syphilis : Ben Venue Lots B103, B104, B111, B114, B116S, B124, B126, B127A, B128, B129, $\mathrm{B} 130$, and Commercial Solvents Lots B471217S, B471231S, B480210, and B480212. 


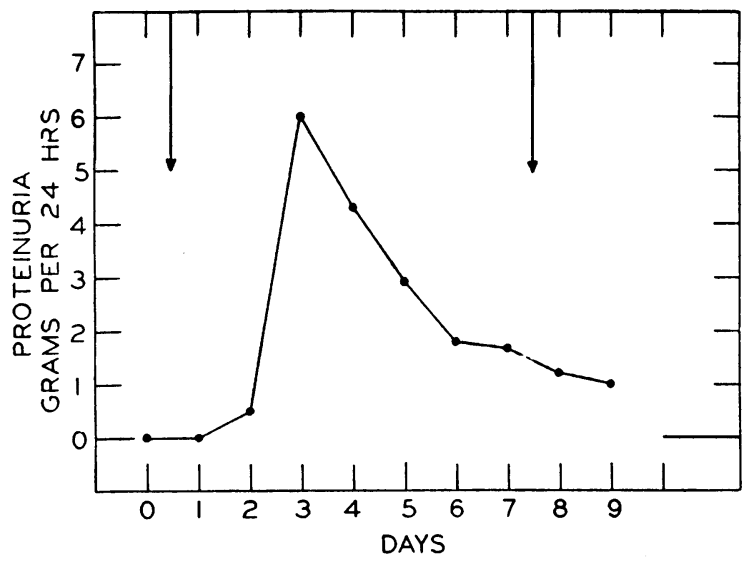

Fig. 1. Proteinuria Following Bacitracin

Mean values for a group of 29 patients with early syphilis receiving 400 units of bacitracin per kilogram body weight every six hours for seven days. Arrows represent beginning and end of treatment.

The present study was undertaken to determine the type of renal functional alterations produced by the parenteral administration of bacitracin in man and to determine the degree and duration of depression of renal function incident to the use of this antibiotic.

\section{EXPERIMENTAL}

Twelve normotensive male subjects, who showed no clinical evidence of cardiovascular or renal disease and who were free of infectious disease, were studied before and after the parenteral administration of bacitracin, uti-

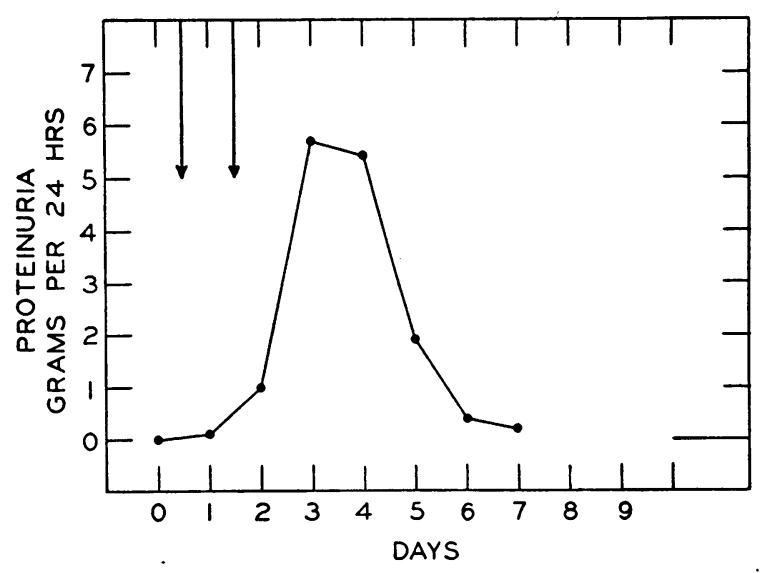

Fig. 2. Proteinuria Following Bacitracin

Mean values for a group of 15 patients with early syphilis receiving 1,500 units of bacitracin per kilogram body weight in a single injection for two successive days. Arrows represent beginning and end of treatment. lizing the clearance and saturation techniques devised by Smith and his associates (10-12). One subject (L. R.), who fulfilled the above criteria for selection, was found to have abnormally low renal function during control studies, but was nevertheless included in the present study. Clearance of inulin $\left(\mathrm{C}_{\mathrm{IN}}\right)$, clearance of sodium $p$ aminohippurate $\left(\mathrm{C}_{\mathbf{P A}}\right)$, and the maximal tubular excretory rate of sodium $p$-aminohippurate $\left(\mathrm{Tm}_{\mathrm{PAB}}\right)$ were followed in six subjects. A second group of six subjects was followed with determinations of the clearance of inulin and the maximal tubular rate of glucose reabsorption $\left(T \mathrm{~m}_{\mathrm{G}}\right)$.

Following baseline determinations of the above functions as well as of blood non-protein nitrogen and urea nitrogen, bacitracin 2 was administered intramuscularly in a dosage of 1,500 units per kilogram body weight followed by a second injection of the same magnitude 24 hours later. This dosage was selected to correspond to the daily therapeutic dosage employed by others in the treatment of various surgical and medical infections (2, $4,5)$. Two different lots of bacitracin, Lot B129 (Ben Venue) and Lot B480210 (Commercial Solvents), were used in the present study. The group in which $\mathrm{Tm}_{\mathrm{PAH}}$ was followed received Lot B129, while the group in which $\mathrm{Tm}_{\mathrm{G}}$ was followed received Lot B480210.

Subsequent to the administration of bacitracin, renal function studies and blood chemistry determinations were repeated at three to seven day intervals until baseline or near baseline values were again reached. Serial quantitative determinations of 24 hour urinary protein as well as routine urinalyses including microscopic examination of sediment of freshly voided urine were performed daily for 30 to 60 days following the administration of bacitracin.

Inulin was determined by Harrison's modification of the method of Alving $(13,14)$. PAH was determined in cadmium sulfate filtrates of plasma and in diluted urine by the method of Bratton and Marshall (15). Glucose determinations were made according to the method of Nelson (16). Urinary protein was determined by measurement of the volume of precipitate formed with phosphotungstic acid in acid alcohol (17). Blood urea nitrogen and non-protein nitrogen were determined by the manometric methods of Van Slyke $(18,19)$.

\section{RESULTS}

Following the parenteral administration of bacitracin, proteinuria appeared at 48 to 60 hours in all subjects, was at a maximum for 48 hours after its appearance, and then decreased rapidly to levels below 0.5 gram per day by the seventh day in 11 of 12 subjects (Table I). Maximum proteinuria ranged from 0.7 to 9.7 grams per 24 hours in individual subjects, with a mean of 4.4 grams.

2 The bacitracin employed in this study was provided by Dr. Frank L. Meleney. 
TABLE I

Proteinuria following the intramuscular administration of 1500 units of bacitracin per kilogram body weight on two successive days*

\begin{tabular}{|c|c|c|c|c|c|c|c|c|c|c|c|}
\hline \multirow{2}{*}{$\begin{array}{l}\text { Sub- } \\
\text { ject }\end{array}$} & \multirow{2}{*}{$\begin{array}{l}\text { Con- } \\
\text { trol }\end{array}$} & \multicolumn{10}{|c|}{ Proteinuria-grams per 24 hours } \\
\hline & & $\begin{array}{c}\text { Day } \\
1\end{array}$ & $\begin{array}{c}\text { Day } \\
2\end{array}$ & Day $_{3}$ & $\begin{array}{c}\text { Day } \\
\mathbf{4}\end{array}$ & $\begin{array}{c}\text { Day } \\
5\end{array}$ & $\begin{array}{c}\text { Day } \\
6\end{array}$ & $\begin{array}{c}\text { Day } \\
7\end{array}$ & $\begin{array}{c}\text { Day } \\
8\end{array}$ & $\begin{array}{c}\text { Day } \\
9\end{array}$ & $\begin{array}{c}\text { Day } \\
10\end{array}$ \\
\hline $\begin{array}{l}\mathrm{EH} \\
\mathrm{CW} \\
\mathrm{AA} \\
\mathrm{CW} \\
\mathrm{EN} \\
\mathrm{LR} \\
\mathrm{CR} \\
\mathrm{FC} \\
\mathrm{CB} \\
\mathrm{RB} \\
\mathrm{RN} \\
\text { OS } \\
\text { JB }\end{array}$ & $\begin{array}{c}0.0 \\
\dagger \\
+ \\
0.0 \\
0.0 \\
+ \\
\vdots \\
\vdots \\
0.0 \\
0.0 \\
0.0 \\
t\end{array}$ & $\begin{array}{c}0.0 \\
t \\
0.0 \\
0.0 \\
0.2 \\
0.1 \\
t \\
t \\
0.1 \\
t \\
t \\
t\end{array}$ & $\begin{array}{c}0.0 \\
0.2 \\
0.0 \\
+ \\
1.3 \\
0.4 \\
\dot{t} \\
0.3 \\
0.4 \\
0.3 \\
0.5 \\
t\end{array}$ & $\begin{array}{l}4.8 \\
2.6 \\
\dagger \\
4.6 \\
9.3 \\
0.6 \\
0.6 \\
3.1 \\
9.7 \\
4.4 \\
5.2 \\
0.4\end{array}$ & $\begin{array}{l}5.1 \\
3.0 \\
1.2 \\
3.7 \\
9.2 \\
1.0 \\
1.3 \\
3.4 \\
3.4 \\
7.0 \\
6.7 \\
0.5\end{array}$ & $\begin{array}{l}2.7 \\
1.4 \\
1.1 \\
0.8 \\
3.2 \\
0.4 \\
1.0 \\
1.3 \\
3.1 \\
4.8 \\
4.7 \\
0.7\end{array}$ & $\begin{array}{l}0.3 \\
0.4 \\
\dagger \\
0.1 \\
0.4 \\
0.2 \\
0.2 \\
0.5 \\
0.4 \\
2.3 \\
1.2 \\
0.3\end{array}$ & $\begin{array}{c}t \\
0.2 \\
t \\
0.3 \\
t \\
0.2 \\
\dagger \\
0.3 \\
0.0 \\
1.9 \\
0.3 \\
t\end{array}$ & $\begin{array}{l}0.1 \\
0.4 \\
\dagger \\
0.3 \\
0.2 \\
0.1 \\
0.3 \\
0.2 \\
0.0 \\
1.8 \\
0.3 \\
0.1\end{array}$ & $\begin{array}{c}0.0 \\
0.3 \\
\dagger \\
0.3 \\
\dagger \\
0.2 \\
0.2 \\
0.3 \\
0.0 \\
1.2 \\
0.2 \\
0.3\end{array}$ & $\begin{array}{c}t \\
\ddagger \\
\dagger \\
0.1 \\
t \\
\dagger \\
0.2 \\
t \\
0.2 \\
0.8 \\
t \\
t\end{array}$ \\
\hline Mean & 0.00 & 0.03 & 0.28 & 3.78 & 3.79 & 2.10 & 0.53 & 0.27 & 0.32 & 0.25 & 0.11 \\
\hline
\end{tabular}

* Bacitracin administered at beginning of Day 1 and Day 2.

† Less than 0.1 gram per 24 hours.

Concomitantly with the onset of proteinuria, there appeared in the urine numerous tubular epithelial cells together with granular, hyaline, and epithelial cell casts. The absence of microscopic hematuria was striking. Epithelial cells and casts were present in large numbers in the urine for 48 hours, following which they paralleled proteinuria in their disappearance. Fasting glycosuria occurred during the period of proteinuria in 10 of 12 subjects.

Renal function studies were performed 84 hours after the administration of bacitracin, i.e., during the period of maximal proteinuria, in all subjects. The clearance of inulin $\left(\mathrm{C}_{\mathrm{IN}}\right)$ was depressed at this time in 10 of 12 subjects. The depression ranged from 6.7 to 74.6 per cent with a mean of 33.6 per cent. The mean depression for the entire group of 12 subjects was 27.6 per cent (Tables II and III). Following the period of proteinuria, the mean for the group gradually increased until, at nine weeks, it was only 8 per cent below the baseline value (Figures 3 and 4 ). Of the 10 subjects who showed a decrease in $\mathrm{C}_{\mathrm{IN}}$ following bacitracin, nine had returned to within 15 per cent of baseline value by the ninth week. The tenth subject was lost to the study at seven weeks with a depression of 20.5 per cent.

The clearance of $p$-aminohippurate $\left(\mathrm{C}_{\mathbf{P A H}}\right)$ was decreased in five of six subjects 84 hours after the administration of bacitracin. The depression varied from 5.1 to 76 per cent with a mean of 25.7 per cent. The mean depression for the entire group of six was 18.0 per cent (Table II). $\mathrm{C}_{\mathbf{P A B}}$ returned to baseline values more rapidly than did

TABLE II

Clearance of inulin, clearance of $P A H$, and tubular excretory capacity for $P A H$ following bacitracin*

\begin{tabular}{|c|c|c|c|c|c|c|c|c|c|c|c|c|c|c|}
\hline \multirow[t]{2}{*}{ Subject } & \multirow[t]{2}{*}{ Meas. } & \multirow[t]{2}{*}{ Control } & \multicolumn{2}{|c|}{ 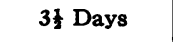 } & \multicolumn{2}{|c|}{ 7-10 Days } & \multicolumn{2}{|c|}{ 14-17 Days } & \multicolumn{2}{|c|}{ 28-31 Days } & \multicolumn{2}{|c|}{ 42-45 Days } & \multicolumn{2}{|c|}{ 63-66 Days } \\
\hline & & & & $\begin{array}{l}\text { per cent } \\
\text { change }\end{array}$ & & $\begin{array}{l}\text { per cent } \\
\text { change }\end{array}$ & & $\begin{array}{l}\text { er cent } \\
\text { hange }\end{array}$ & & $\begin{array}{l}r \text { cent } \\
\text { hange }\end{array}$ & & & & \\
\hline EH & $\mathrm{C}_{\mathrm{IN}}$ & 90 & 84 & -6.7 & 88 & -2.2 & 93 & +3.3 & $t$ & $t$ & $t$ & & $t$ & \\
\hline & $\begin{array}{l}\text { CPAB } \\
\text { Tm }_{\text {PAH }}\end{array}$ & $\begin{array}{r}550 \\
70\end{array}$ & $\begin{array}{r}411 \\
49\end{array}$ & $\begin{array}{l}-25.3 \\
-30.0\end{array}$ & $\begin{array}{r}488 \\
59\end{array}$ & $\begin{array}{l}-11.3 \\
-15.7\end{array}$ & $\begin{array}{r}545 \\
73\end{array}$ & $\begin{array}{l}-0.9 \\
+\quad 4.3\end{array}$ & & & & & & \\
\hline $\mathrm{CWi}$ & $\mathrm{C}_{\mathrm{IN}}$ & 136 & 98 & -27.9 & 86 & -36.8 & 103 & -24.3 & 118 & -13.2 & 130 & -4.4 & 116 & -14.7 \\
\hline & $\mathrm{C}_{\text {PAH }}$ & 414 & 393 & -5.1 & 350 & -15.4 & 381 & -8.0 & 409 & -1.2 & 436 & +5.3 & 390 & -5.8 \\
\hline & $T_{\text {PAH }}$ & 95 & 51 & -46.3 & 64 & -32.6 & 64 & -32.6 & 67 & -29.5 & 70 & -26.3 & 84 & -11.6 \\
\hline AA & $\mathrm{C}_{\mathrm{IN}}$ & 104 & 92 & -11.5 & 92 & -11.5 & 93 & -10.6 & 91 & -12.5 & $t$ & 1 & & \\
\hline & $\mathrm{C}_{\text {PAH }}$ & 513 & 473 & -7.8 & 428 & -16.6 & 425 & -17.1 & 451 & -12.1 & $\dagger$ & & & \\
\hline & $1 \mathrm{~m}$ & 85 & 73 & -14.1 & 65 & -23.5 & 63 & -25.9 & 76 & -10.6 & $\dagger$ & 1 & $t$ & \\
\hline Cwe & $\begin{array}{l}\text { CIN } \\
\text { CPAH }\end{array}$ & $\begin{array}{r}93 \\
305\end{array}$ & 70 & -24.7 & 80 & -14.0 & 84 & -9.7 & 84 & -9.7 & 82 & -11.8 & 86 & -7.5 \\
\hline & $\mathrm{T}_{\mathrm{m}}$ & $\begin{array}{l}395 \\
102\end{array}$ & $\begin{array}{r}343 \\
58\end{array}$ & -13.2 & $\begin{array}{r}344 \\
50\end{array}$ & $\begin{array}{l}-12.9 \\
-42.2\end{array}$ & $\begin{array}{r}428 \\
64\end{array}$ & $\begin{array}{l}+8.4 \\
-373\end{array}$ & 390 & -1.3 & 403 & +2.0 & 474 & $\begin{array}{l}+20.0 \\
-31.4\end{array}$ \\
\hline EN & & 127 & 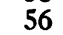 & -55.9 & 55 & -56.7 & 63 & -50.4 & 88 & -30.7 & 102 & $\begin{array}{l}-28.4 \\
-19.7\end{array}$ & 117 & $\begin{array}{l}-31.4 \\
-\quad 7.9\end{array}$ \\
\hline & $\mathrm{C}_{\text {PAH }}$ & 638 & 153 & -76.0 & 370 & -42.0 & 408 & -36.1 & 665 & +4.2 & 665 & +4.2 & 664 & +4.1 \\
\hline & $\operatorname{Tm}_{\mathrm{PAB}}$ & 91 & 14 & -84.6 & 58 & -36.3 & 78 & -14.3 & 84 & -7.7 & 80 & -12.1 & 76 & -16.5 \\
\hline LR & $\mathrm{C}_{\text {IN }}$ & 49 & 35 & -28.6 & 34 & -30.6 & 39 & -20.4 & 38 & -22.4 & 43 & -12.2 & A & \\
\hline & & 187 & 223 & +19.3 & 176 & -5.9 & 210 & +12.3 & 223 & +19.3 & 221 & +18.2 & & \\
\hline Mean & $\hat{C}_{\text {IN }}^{I_{\text {PAH }}}$ & $\begin{array}{r}49 \\
100\end{array}$ & $\begin{array}{l}40 \\
73\end{array}$ & $\begin{array}{l}-18.4 \\
-25.9\end{array}$ & 73 & $\begin{array}{l}-12.2 \\
-25.3\end{array}$ & $\begin{array}{l}39 \\
79\end{array}$ & $\begin{array}{l}-20.4 \\
-18.7\end{array}$ & $\begin{array}{l}45 \\
85\end{array}$ & $\begin{array}{r}-8.2 \\
-142\end{array}$ & $\begin{array}{l}49 \\
91\end{array}$ & $\begin{array}{r}0.0 \\
-\quad 91\end{array}$ & t & -8.1 \\
\hline & $\mathrm{C}_{\text {PAH }}$ & 450 & 333 & -18.0 & 359 & -17. & 400 & - & 422 & -3 & 454 & $\begin{array}{l}7.1 \\
+\quad 2.8\end{array}$ & 458 & $\begin{array}{l}0.1 \\
+\quad 3.9\end{array}$ \\
\hline & & & & -3 & & -27 & 64 & -21.0 & & -1 & 70 & -12.4 & 71 & -11.2 \\
\hline
\end{tabular}

* All values represent the mean of three to five urine collection periods.

† Subject dropped from study either because baseline values had been attained or for some extraneous reason. Last obtained values extended in the calculation of the mean for the group. 
TABLE III

Clearance of inulin and tubular reabsorptive capacity for glucose following bacitracin*

\begin{tabular}{|c|c|c|c|c|c|c|c|c|c|c|c|c|c|c|}
\hline Subject & Meas. & Control & & Days & & 0 Days & & 7 Days & & 24 Days & & 1 Days & $49-$ & 2 Days \\
\hline FC & $\begin{array}{l}\mathrm{C}_{\mathrm{IN}} \\
\mathrm{T}_{\mathrm{m}}\end{array}$ & $\begin{array}{l}121 \\
309\end{array}$ & $\begin{array}{l}122 \\
332\end{array}$ & $\begin{array}{c}\text { per cent } \\
\text { change } \\
+0.8 \\
+7.4\end{array}$ & $\begin{array}{l}117 \\
312\end{array}$ & $\begin{array}{c}\text { per cent } \\
\text { change } \\
-3.3 \\
+1.0\end{array}$ & $\begin{array}{l}119 \\
326\end{array}$ & $\begin{array}{c}\text { per cent } \\
\text { change } \\
-1.7 \\
+\quad 5.5\end{array}$ & $\begin{array}{l}121 \\
340\end{array}$ & $\begin{array}{r}\text { per cent } \\
\text { change } \\
0.0 \\
+10.0\end{array}$ & $t$ & $\begin{array}{c}\text { per cent } \\
\text { change } \\
\dagger \\
\dagger\end{array}$ & $t$ & $\begin{array}{c}\text { per cent } \\
\text { change } \\
\dagger \\
\dagger\end{array}$ \\
\hline $\mathrm{JC}$ & $\begin{array}{l}\mathrm{C}_{\mathrm{IN}} \\
\mathrm{Tm}_{G}\end{array}$ & $\begin{array}{l}121 \\
316\end{array}$ & $\begin{array}{l}101 \\
300\end{array}$ & $\begin{array}{l}-16.5 \\
-\quad 5.1\end{array}$ & $\begin{array}{r}87 \\
221\end{array}$ & $\begin{array}{l}-28.1 \\
-30.0\end{array}$ & $\begin{array}{r}96 \\
264\end{array}$ & $\begin{array}{l}-20.7 \\
-16.5\end{array}$ & $\begin{array}{l}105 \\
306\end{array}$ & $\begin{array}{l}-13.2 \\
-\quad 3.2\end{array}$ & $\dagger$ & $t$ & $t$ & $\dagger$ \\
\hline RB & $\begin{array}{l}\mathrm{C}_{\mathrm{IN}} \\
\mathrm{Tm}_{\mathrm{G}}\end{array}$ & $\begin{array}{r}92 \\
277\end{array}$ & $\begin{array}{r}53 \\
104\end{array}$ & $\begin{array}{l}-42.4 \\
-62.5\end{array}$ & $\begin{array}{r}57 \\
139\end{array}$ & $\begin{array}{l}-38.0 \\
-49.8\end{array}$ & $\begin{array}{r}77 \\
157\end{array}$ & $\begin{array}{l}-16.3 \\
-43.3\end{array}$ & $\begin{array}{r}77 \\
189\end{array}$ & $\begin{array}{l}-16.3 \\
-31.8\end{array}$ & $\begin{array}{r}77 \\
181\end{array}$ & $\begin{array}{l}-16.3 \\
-34.7\end{array}$ & $\begin{array}{r}87 \\
250\end{array}$ & $\begin{array}{l}-5.4 \\
-9.7\end{array}$ \\
\hline RN & $\begin{array}{l}\mathrm{C}_{\mathrm{IN}} \\
\mathrm{Tm}_{\mathrm{G}}\end{array}$ & $\begin{array}{l}118 \\
320\end{array}$ & $\begin{array}{l}30 \\
77\end{array}$ & $\begin{array}{l}-74.6 \\
-75.9\end{array}$ & $\begin{array}{l}39 \\
96\end{array}$ & $\begin{array}{l}-66.9 \\
-70.0\end{array}$ & $\begin{array}{r}50 \\
143\end{array}$ & $\begin{array}{l}-57.6 \\
-55.3\end{array}$ & $\begin{array}{r}62 \\
216\end{array}$ & $\begin{array}{l}-47.5 \\
-32.5\end{array}$ & $\begin{array}{r}84 \\
266\end{array}$ & $\begin{array}{l}-28.8 \\
-16.9\end{array}$ & $\begin{array}{l}104 \\
305\end{array}$ & $\begin{array}{r}-11.9 \\
-4.7\end{array}$ \\
\hline os & $\begin{array}{l}\mathrm{C}_{\mathrm{IN}} \\
\mathrm{Tm}_{G}\end{array}$ & $\begin{array}{r}78 \\
277\end{array}$ & $\begin{array}{r}41 \\
140\end{array}$ & $\begin{array}{l}-47.4 \\
-49.5\end{array}$ & $\begin{array}{r}50 \\
162\end{array}$ & $\begin{array}{l}-35.1 \\
-41.5\end{array}$ & $\begin{array}{r}53 \\
190\end{array}$ & $\begin{array}{l}-32.1 \\
-31.4\end{array}$ & $\begin{array}{r}57 \\
217\end{array}$ & $\begin{array}{l}-26.9 \\
-21.7\end{array}$ & $\begin{array}{r}61 \\
218\end{array}$ & $\begin{array}{l}-21.8 \\
-21.3\end{array}$ & $\begin{array}{r}62 \\
225\end{array}$ & $\begin{array}{l}-20.5 \\
-18.8\end{array}$ \\
\hline JB & $\begin{array}{l}\mathrm{C}_{\mathrm{IN}} \\
\mathrm{Tm}_{\mathrm{G}}\end{array}$ & $\begin{array}{r}89 \\
217\end{array}$ & $\begin{array}{r}93 \\
206\end{array}$ & $\begin{array}{l}+4.5 \\
-5.1\end{array}$ & $\begin{array}{r}88 \\
174\end{array}$ & $\begin{array}{l}-1.1 \\
-19.8\end{array}$ & $\begin{array}{r}87 \\
174\end{array}$ & $\begin{array}{l}2.2 \\
-19.8\end{array}$ & $\begin{array}{r}96 \\
267\end{array}$ & $\begin{array}{r}+7.9 \\
+23.0\end{array}$ & $\begin{array}{r}93 \\
254\end{array}$ & $\begin{array}{l}+4.5 \\
+17.1\end{array}$ & $\dagger$ & $t$ \\
\hline Mean & $\begin{array}{l}\mathrm{C}_{\mathrm{IN}} \\
\mathrm{Tm}_{\mathrm{G}}\end{array}$ & $\begin{array}{l}103 \\
286\end{array}$ & $\begin{array}{r}73 \\
193\end{array}$ & $\begin{array}{l}-29.3 \\
-31.8\end{array}$ & $\begin{array}{r}73 \\
184\end{array}$ & $\begin{array}{l}-28.8 \\
-35.0\end{array}$ & $\begin{array}{r}80 \\
1209 .\end{array}$ & $\begin{array}{l}-21.8 \\
-26.8\end{array}$ & $\begin{array}{r}86 \\
256\end{array}$ & $\begin{array}{r}-16.0 \\
-9.4\end{array}$ & $\begin{array}{r}90 \\
261\end{array}$ & $\begin{array}{l}-12.6 \\
-8.2\end{array}$ & $\begin{array}{r}95 \\
280\end{array}$ & $\begin{array}{l}-7.8 \\
-1.6\end{array}$ \\
\hline
\end{tabular}

* All values represent the mean of three to five urine collection periods.

$\dagger$ Subject dropped from study either because baseline values had been attained or for some extraneous reason. Last obtained values extended in the calculation of the mean for the group.

$\mathrm{C}_{\mathrm{IN}}$. By six weeks the mean $\mathrm{C}_{\mathrm{PAH}}$ for the entire group was 3 per cent above the baseline value, and all of the subjects had returned to within 12 per cent of the baseline value. In order to elucidate the mechanism of the observed depression in $\mathrm{C}_{\mathbf{P A B}}$, an additional subject was studied both before and
84 hours after the administration of bacitracin, utilizing the technique of catheterization of the right renal vein (20). In this individual the renal extraction of $\mathrm{PAH}$ at low plasma levels was markedly depressed from a baseline value of 91 per cent to a post-bacitracin value of 15.4 per cent.

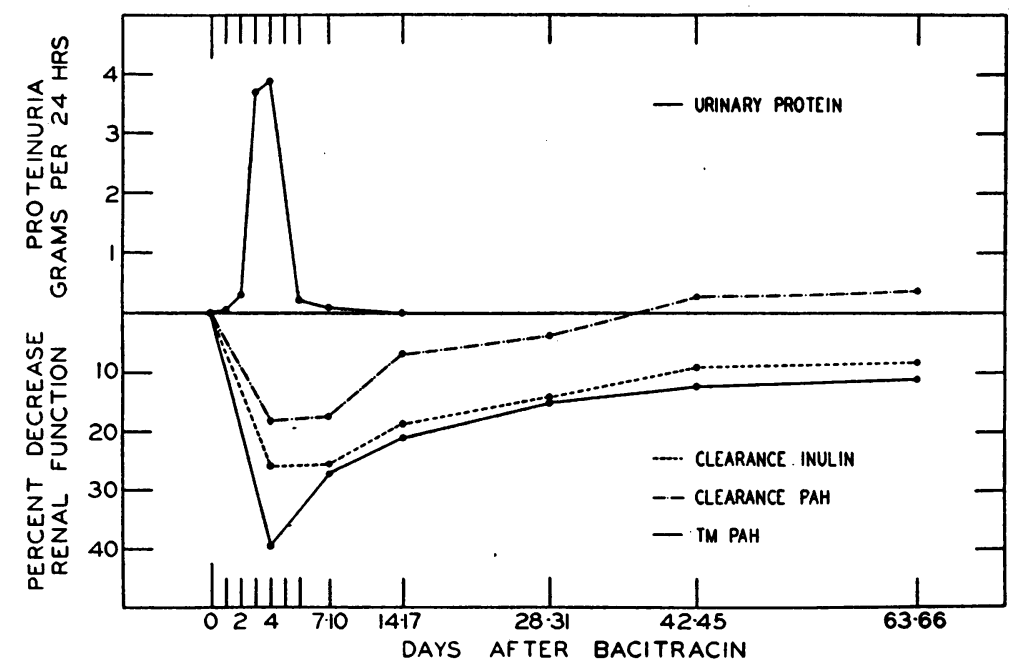

Fig. 3. Renal Function Following Bacitracin

Mean values for a group of six subjects following the injection of 1,500 units of bacitracin per kilogram body weight on two successive days. Bacitracin from Lot B129 (surface culture preparation, Ben Venue). 


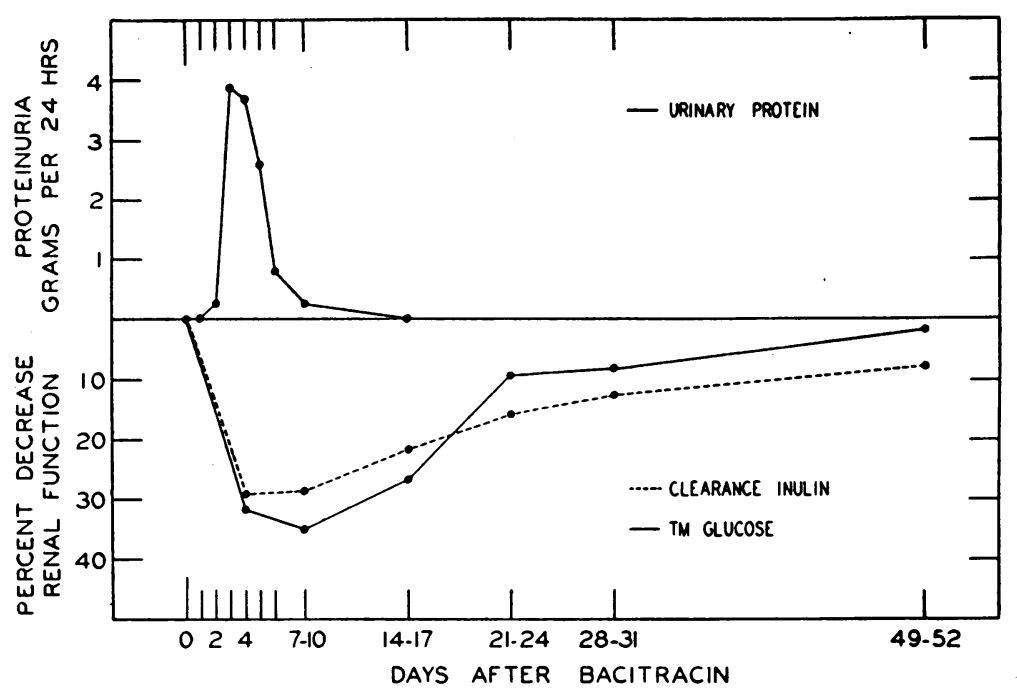

Fig. 4. Renal Function Following Bacitracin

Mean values for a group of six subjects following the injection of 1,500 units of bacitracin per kilogram body weight on two successive days. Bacitracin from Lot B480210 (deep tank preparation, Commercial Solvents Corp.).

Six of six subjects showed a decreased $\mathrm{Tm}_{\mathbf{P A B}}$ at the time of maximal proteinuria. Individual depressions ranged from 14.1 to 84.6 per cent with a mean of 39.4 per cent (Table II). After seven days, the depression of $\mathrm{Tm}_{\mathrm{PAB}}$ for the entire group closely paralleled the depression of $\mathrm{C}_{\mathrm{IN}}$ (Figure 3 ). The mean depression for the group at nine weeks was 11 per cent below the baseline value. At that time two individuals still showed a decrease of more than 15 per cent.

$\mathrm{Tm}_{\mathrm{G}}$ was depressed at 84 hours in five of six subjects (Table III). The depressions varied between 5.1 and 75.9 per cent with a mean of 39.6 per cent. The mean depression for the group of six was 31.8 per cent. By seven weeks $\mathrm{Tm}_{\mathrm{G}}$ had returned to within 10 per cent of baseline values in all except -one subject who showed a decrease of 18.8 per cent at that time and who was subsequently lost to the study. The mean for the entire group at seven weeks was 1.6 per cent below the baseline value (Figure 4 ).

Blood urea nitrogen was significantly elevated from the baseline mean of $10.58 \mathrm{mg}$. per cent to $16.26 \mathrm{mg}$. per cent at 84 hours $(\mathrm{t}=3.68 ; \mathrm{P}=$ $<.01)$. The elevation in BUN roughly paralleled the depression in $\mathrm{C}_{\mathrm{IN}}$ in its return to baseline values. No change in arterial blood pressure oc- curred during the post-bacitracin observation period.

\section{DISCUSSION}

Following the parenteral administration of therapeutic doses of bacitracin in man, there occurs an acute depression in $\mathrm{C}_{\mathrm{IN}}, \mathrm{C}_{\mathrm{PAH}}, \mathrm{Tm}_{\mathrm{PAH}}$, and $\mathrm{Tm}_{\mathrm{G}}$, followed by a gradual return of these functions over a period of several months to baseline values.

The depression in $\mathrm{C}_{\mathrm{IN}}$ may be interpreted in several ways. First, mechanical obstruction of the tubules by casts and epithelial cells may be responsible for a decrease in glomerular filtration rate. In view of the fact that the presence of protein, casts, and epithelial cells in the urine was an acute process persisting for only a few days, while the depression in $\mathrm{C}_{\mathrm{IN}}$ continued for a number of weeks, it seems unlikely that mechanical obstruction, alone, could account for the observed depression in $\mathrm{C}_{\mathrm{IN}}$.

Secondly, tubular injury may result in the passive reabsorption of inulin from the glomerular filtrate. In such circumstances the clearance of inulin would no longer be a measure of the glomerular filtration rate. This interpretation seems equally untenable inasmuch as the depression in $\mathrm{C}_{\text {IN }}$ persisted for weeks after the acute phase during which tubular epithelial cells, casts and pro- 
tein were present in the urine.

Furthermore, disparity between $\mathrm{C}_{\mathrm{IN}}$ and $\mathrm{Tm}$ depressions occurred in individual patients. In subjects E. N. and L. R., Tm $\mathrm{PAH}_{\mathrm{PA}}$ returned to control levels over a period of one month following bacitracin, while $\mathrm{C}_{\mathrm{IN}}$ remained persistently depressed. This would seem to indicate impairment in glomerular function beyond four weeks which cannot be explained on the basis of passive diffusion of inulin through damaged tubules.

It would seem most likely, then, that the decrease in $\mathrm{C}_{\text {IN }}$ observed cannot be entirely accounted for by mechanical obstruction of tubules and/or passive diffusion of inulin back through damaged tubular cells, and that injury to the glomerulus itself probably occurred.

The depression observed in $\mathrm{C}_{\mathbf{P A H}}$ might be explained on the basis of a decreased renal plasma flow or on the basis of reduced ability of damaged tubules to extract PAH at low plasma levels. It it evident from the results obtained in the additional subject studied by catheterization of the renal vein before and after bacitracin (Table IV) that the depression in $\mathrm{C}_{\mathrm{PAB}}$ was due largely to tubular damage rather than to a decrease in renal plasma flow. As contrasted with a decrease of 88.4 per cent in $\mathrm{C}_{\mathbf{P A H}}$, true renal plasma flow decreased only 28.7 per cent.

It should be noted that the decrease in $\mathrm{C}_{\mathbf{P A H}}$ which occurred in this individual was considerably greater than the mean $\mathrm{C}_{\mathbf{P A H}}$ depression of 18.0 per cent for the entire group. In view of the fact that $\mathrm{C}_{\mathbf{P A B}}$ depression following bacitracin has been demonstrated to be due largely to tubular damage, it seems unlikely that renal vasoconstriction and decreased renal blood flow played any significant role in the reduction of glomerular filtration rate. This view is supported by the ab-

TABLE IV

Renal extraction of $P A H$ and renal plasma flow before and after bacitracin*

\begin{tabular}{l|c|c|c}
\hline \hline & Control & $\begin{array}{c}3 \frac{1}{2} \text { Days } \\
\text { post } \\
\text { bacitracin }\end{array}$ & $\begin{array}{c}\text { Per cent } \\
\text { change }\end{array}$ \\
\hline $\mathrm{C}_{\mathrm{IN}}, c c . /$ min. & 88 & 12 & -86.0 \\
$\mathrm{C}_{\mathrm{PAH}}, c c . /$ min. & 318 & 37 & -88.4 \\
$\mathrm{Tm}_{\mathrm{PAB}}$ mg./min. & 76 & 2.6 & -96.6 \\
$\mathrm{PAH}$ Extraction, per cent & 91.0 & 15.4 & $-\overline{28.7}$ \\
$\mathrm{RPF}, c c . /$ min. & 349 & 249 & - \\
\hline
\end{tabular}

* Values represent the mean of three urine collection periods. sence of change in arterial blood pressure, and by the observation that the mean $\mathrm{C}_{\mathbf{P A B}}$ returned to baseline values at four weeks, while the mean $C_{\text {IN }}$ was still depressed at nine weeks following bacitracin.

Additional evidence of tubular damage is presented by the appearance of tubular epithelial cells in the urine, the occurrence of glycosuria in the post-absorptive state, and the depression in tubular excretory and reabsorptive capacity for $\mathrm{PAH}$ and glucose respectively. Load to $\mathrm{Tm}$ ratios were as high in the post-bacitracin studies (i.e., 2:1 to $3: 1$ ) as in the control studies.

\section{SUMMARY AND CONCLUSIONS}

1. Parenteral administration of the polypeptide antibiotic substance, bacitracin, in therapeutic doses is followed uniformly by the occurrence of proteinuria and the appearance of renal tubular epithelial cells in the urine, and frequently by the occurrence of glycosuria in the post-absorptive state.

2. During the period of proteinuria there occurs an acute depression of tubular function and probably also of glomerular function, as manifested by a decrease in the clearances of inulin and PAH, a decrease in the tubular excretory capacity for $\mathrm{PAH}$, a decrease in the tubular reabsorptive capacity for glucose, and a decrease in the renal extraction of $\mathrm{PAH}$ at low plasma levels.

3. Although proteinuria is present for only six to 10 days following two injections of 1,500 units of bacitracin per kilogram body weight, both glomerular and tubular function remain depressed over a period of weeks, returning only gradually to baseline levels at seven to nine weeks.

Since this work was submitted for publication, a number of reports (21-25), relating to the toxicity of bacitracin have appeared.

\section{ACKNOWLEDGMENT}

The authors express their appreciation to Mrs. Elsie Beard, Miss Margaret McCollom, Mr. Irving Jones, and Mr. Arthur Dinan for technical assistance.

\section{BIBLIOGRAPHY}

1. Johnson, B. A., Anker, H., and Meleney, F. L., Bacitracin: A new antibiotic produced by a member of the $B$. subtilis group. Science, 1945, 102, 376. 
2. Meleney, F.L., Altemeier, W. A., Longacre, A. B., Pulaski, E. J., and Zintel, H. A., The results of the systemic administration of the antibiotic, bacitracin, in surgical infections. A preliminary report. Ann. Surg., 1948, 128, 714.

3. Eagle, H., and Fleischman, R., Therapeutic activity of bacitracin in rabbit syphilis and its synergistic action with penicillin. Proc. Soc. Exper. Biol. \& Med., 1948, 68, 415.

4. Meleney, F. L., Personal communication. (See references 21 and 22.)

5. Pulaski, E. J., and Connell, J. F., Jr., Bacitracin in surgical wound infections. Bull. U. S. Army Med. Dept., 1949, 9, 141.

6. Scudi, J. V., and Antopol, W., Some pharmacological characteristics of bacitracin. Proc. Soc. Exper. Biol. \& Med., 1947, 64, 503.

7. Nelson, A. A., and Hagan, E. C., Comparison of different lots of bacitracin for nephrotoxicity to rats and mice. Federation Proc., 1949, 8, 363.

8. Scudi, J. V., Coret, I. A., and Antopol, W., Some pharmacological characteristics of bacitracin. III. Chronic toxicity studies of commercial bacitracin in the dog and monkey. Proc. Soc. Exper. Biol. \& Med., 1947, 66, 558.

9. Miller, J. H., Unpublished data.

10 Goldring, W., Chasis, H., Ranges, H. A., and Smith, H. W., Relations of effective renal blood flow and glomerular filtration to tubular excretory mass in normal man. J. Clin. Invest., 1940, 19, 739.

11. Goldring, W., and Chasis, H., Hypertension and $\mathrm{Hy}-$ pertensive Disease. The Commonwealth Fund, New York, 1944.

12. Smith, H. W., Finkelstein, N., Aliminosa, L., Crawford, B., and Graber, M., The renal clearances of substituted hippuric acid derivatives and other aromatic acids in dog and man. J. Clin. Invest., 1945, 24, 388.

13. Harrison, H. E., A modification of the diphenylamine method for the determination of inulin. Proc. Soc. Exper. Biol. \& Med., 1942, 49, 111.

14. Alving, A. S., Rubin, J., and Miller, B. F., A direct colorimetric method for the determination of inu- lin in blood and urine. J. Biol. Chem., 1939, 127, 609.

15. Bratton, A. C., and Marshall, E. K., Jr., A new coupling component for sulfanilamide determination. J. Biol. Chem., 1939, 128, 537.

16. Nelson, N., A photometric adaptation of the Somogyi method for the determination of glucose. J. Biol. Chem., 1944, 153, 375.

17. Todd, J. C., and Sanford, A. H., Clinical Diagnosis by Laboratory Methods. W. B. Saunders Co., Philadelphia, 1943. (10th Ed.)

18. Van Slyke, D. D., Determination of urea by gasometric measurement of the carbon dioxide formed by the action of urease. J. Biol. Chem., 1927, 73, 695.

19. Van Slyke, D. D., Gasometric micro-Kjeldahl determination of nitrogen. J. Biol. Chem., 1927, 71, 235.

20. Warren, J. V., Brannon, E. S., and Merrill, A. J., A method of obtaining renal venous blood in unanesthetized persons with observations on the extraction of oxygen and sodium para-aminohippurate. Science, 1944, 100, 108.

21. Meleney, F. L., Longacre, A. B., Altemeier, W. A., Reisner, E. H., Jr., Pulaski, E. J., and Zintel, H. A., The efficacy and the safety of the intramuscular administration of bacitracin in various types of surgical and certain medical infections. Surg., Gynec. \& Obstet., 1949, 89, 657.

22. Meleney, F. L., and Johnson, B. A., Bacitracin. Am. J. Med., 1949, 7, 794.

23. Michie, A. J., Zintel, H. A., Ma, R. A., Ravdin, I. S., and Ragni, M., The nephrotoxicity of bacitracin in man. Surgery, 1949, 26, 626.

24. Smith, L. W., Schultz, F. H., Jr., Ott, W. L., and Payne, H. G., A comparative study of the renal damage produced in mice by various lots of bacitracin. J. Clin. Invest., 1949, 28, 1018.

25. Zintel, H. A., Ma, R. A., Nichols, A. C., and Ellis, H., The absorption, distribution, excretion and toxicity of bacitracin in man. Am. J. M. Sc., 1949, 218, 439. 